\title{
Housing Affordability and the Organized Private Sector Housing in Nigeria
}

\author{
Samson Akinbamide Omobayo Adegoke ${ }^{1 *}$, Tunde Agbola ${ }^{2}$ \\ ${ }^{1}$ Department of Estate Management and Valuation, Osun State College of Technology, Esa-Oke, Osun State, Nigeria \\ ${ }^{2}$ Department of Urban and Regional Planning University Of Ibadan, Oyo State, Nigeria \\ Email: ^adegokesao@oscotechesaoke.edu.ng, babatundeagbola@yahoo.com
}

How to cite this paper: Adegoke, S. A. O. \& Agbola, T. (2020). Housing Affordability and the Organized Private Sector Housing in Nigeria. Open Journal of Social Sciences, $8,177-192$.

https://doi.org/10.4236/jss.2020.84013

Received: February 7, 2020

Accepted: April 12, 2020

Published: April 15, 2020

Copyright $\odot 2020$ by author(s) and Scientific Research Publishing Inc. This work is licensed under the Creative Commons Attribution International License (CC BY 4.0).

http://creativecommons.org/licenses/by/4.0/

(c) (i) Open Access

\begin{abstract}
Growing housing deficit in Nigeria, particularly in urban areas, has resulted to various housing problems such as overcrowding, homelessness, slum and squatter developments. Despite the myriad of housing policies and programmes to solve the housing deficit, the desire goals have not been achieved, hence the adoption of organized Private Sector housing delivery in 2002. This research is an assessment of the Affordability of Organized Private Sector Housing Delivery in Nigeria. We adopted cross-sectional survey and multi-stage sampling technique. Two states with the prevalence of organized private sector housing developers (OPSHD) in each of the six (6) geo-political zones of Nigeria were selected. Ten Percent (1950) households were randomly selected from the occupied houses $(19,500)$ in all the estates. The structured questionnaires administered on 1950 household heads focused on demographic characteristics (age, sex, and household size) and housing affordability variables (income, housing expenditure and access to mortgage). Questionnaire administered on OPSHD focused on types of houses produced, selling prices and terms. Affordability rating scale (normal $\leq 30 \%$; tolerable $30.1 \%-50 \%$ and stressed $>50 \%$ ) was used to measure housing affordability. The study revealed that $42.4 \% ; 36.9 \%$ and $20.6 \%$ of households have normal, tolerable and stressed housing affordability respectively. The implication of these findings is that organized private sector housing is not affordable to most Nigerians, particularly the low and medium income households; and therefore need to be assisted. A more efficient mortgage with better penetration among the low and medium income household is desirable. Also, "rent-and-own" option should be considered to enhance affordability of low and medium income households.
\end{abstract}

\section{Keywords}

Organized Private Sector Housing Developer, Housing Expenditure, Housing 
Affordability Profile, Housing Affordability Rating Scale, Mortgage

Penetration

\section{Introduction}

Housing problem in Nigeria, particularly the urban centres, has assumed a crisis proportion. This problem is escalating by the day (Egunjobi, 1980; Agbola, 1998; Mabogunje, 2004; Nubi, 2004). Despite the myriad of interventions by successive governments, the problem remains unabated. Today, the country's housing deficit has been variously put at between 17 and 20 million units (NBS, 2015; Oyo-Ita, 2017; World Bank, 2018; Centre for Affordable Housing in Africa, 2018). The most disturbing is the paradox in our urban areas where both vacancies and homelessness are on the increase. This is where housing affordability comes in. Thus, in our urban centres today, there are houses for sale and rental that urban dwellers cannot access due to affordability challenges. Therefore, due to many factors, among which are declining real income and increasing costs of homeownership and rental, housing affordability has deteriorated in urban areas across the country. Yet, all housing policies in the country to date have it as their goal to ensure "that all Nigerians have access to decent and sanitary accommodation at affordable costs with secured tenure." This goal remained elusive and this has brought the issue of housing affordability to the fore in public policy discourse. Since the introduction of organized private sector-driven housing delivery in Nigeria, the concern of affordability was heightened. According to Ndubueze (2009), the fact that Nigeria has embarked on a pro-market housing reform that is private sector-driven, has placed affordability concern at the forefront of the Nigerian housing policy discourse. According to Agbola (2004), despite the avowed allocation efficiency of a liberalized housing market preached by its proponents, there are fears that a liberalized housing market may inadvertently or deliberately exclude those belonging to the vulnerable and disadvantaged groups. The focus of this research is to assess the affordability of the housing delivery by the organized private sector in Nigeria.

\section{Conceptual Issues}

Apart from the concept of housing affordability, which is a subject of a ranging global debate, the main theoretical anchor for this research is the neoclassical consumer theory of housing demand (Magbolugbe, et al., 1991). Therefore, the neoclassical theory of consumer choice, "housing and other goods theory" is our main anchor for the research. Hence, "housing affordability" and "housing and other goods theory" will be discussed in this section.

\subsection{Concept of Housing Affordability}

Affordability generally is a measure of ability and capability of consumer to pay 
for goods and services to be consumed. In a market economy, price will not only allocate quantity, but also, the quality of goods and services that each household will consume based on their level of affordability. According to UNCHS/HABITAT (1991), housing affordability is an assessment that relates a particular housing solution to the amount that can be paid for without unduly stretching the payer's resources. This view of affordability is of wider applicability, as it is applicable to renters, as well as those who want to buy their houses without recourse to mortgage facility (UNCHS/HABITAT, 1991). According to Arthur et al. (2002) housing affordability is more difficult to define, to them, it involves the capacity of households to consume housing services; specifically it involves the relationship between household incomes and housing prices and rents. This is aptly captured by MacLennan and Williams (1990) when they gave one of the most quoted definitions of housing affordability. "affordability" is measured with securing some given standard of housing (or different standards) at a price or rent which does not impose, in the eyes of some third party, (usually government) an unreasonable burden on household income." Whitehead (1991) pointed out that definitions usually focus on the relationship between housing expenditure and household income, and that they seek to establish a standard in respect of which the amount of income spent on housing is deemed unaffordable. This standard can be defined in terms of absolute residual income once housing costs have been met or as ratio measure specifying the acceptable proportion to be spent on housing.

However, in a mortgage-based housing delivery system, housing affordability can be conceptualized as the ability and capability of household to access and meet their periodic mortgage obligations without jeopardizing their health or reducing their family nutrients intake (Agbola, 1990; Olatubara \& Agbola, 1992). That is, ability to meet all requirements to qualify to raise enough funds to buy a house. On the other hand, repayment affordability considers the burden imposed on a household of repaying the mortgage and ability to cope without failing to meet other non-housing necessities. Income affordability is simply a measure of the ratio of house prices to household income. Finally, renter housing affordability specifically measures the ability of renter to pay the rent of a minimum standard housing without jeopardizing the ability to meet other non-housing needs. All these variants of housing affordability only further confirms the complexity of housing affordability and its implications for various segments of the population. Measurement of affordability is problematic as what individual household can afford is often underestimated. The often quoted rule of thumb is that household should not spend more than 30 percent of their income on housing unless they choose to do so.

Therefore, according to Arthur et al. (2002) measuring housing affordability is thus complicated by the inability to determine whether household spend more than 30 percent of their income on housing by necessity or by choice. They further identified other measurement problems with housing affordability to include the definition of income, whether permanent or transitory, liquid or illi- 
quid, personal or household and the definition of housing expenditure, whether voluntary or involuntary, total or per unit of housing services, nominal or real rents, mortgage payment or down payment. Similar view had been expressed by Agbola (1990) that statistical studies of what individual household can afford often considerably underrate the ability of the households to improve their housing circumstances over time. This, according to him, is because of the admitted restrictive assumptions underlying the calculation and the snapshot image of household's income, which disregards the income and family life cycles through which household tend to pass. Thus, only the income of the breadwinner is relied upon, thus disregarding the income of other members of the household that are working and who are often willing and able to contribute towards house ownership of their family.

In the context of this study, therefore, affordability is viewed broadly as the ability of the household to meet condition for ownership and or occupation, which will include ability to pay the purchase price of a house, meet rental obligations; and down payments requirements, meeting periodic mortgage repayment obligation without sacrificing the household's health and nourishment. The incomes of the household are considered as all formal and/or informal, incomes accruable to the breadwinner of a household on monthly basis. This is because it is difficult to know the other members of a household that may be willing and able to contribute towards the household housing expenditure. The view of affordability by Agbola and Olatubara (1992) is what Gan. and Hill (2009) called "Repayment Affordability" but which is better described as "Mortgage Affordability." This means that in discussing the concept of housing affordability, there could be five variants. These are general housing affordability, purchase affordability, mortgage (repayment) affordability, income affordability and rental affordability.

\subsection{Housing and Other Goods Theory}

The template is used to format your paper and style the text. All margins, column widths, line spaces, and text fonts are prescribed; please do not alter them. You may note peculiarities. For example, the head margin in this template measures proportionately more than is customary. This measurement and others are deliberate, using specifications that anticipate your paper as one part of the entire journals, and not as an independent document. Please do not revise any of the current designations.

The general theoretical base for fully develop theory of the housing market for analyzing housing decisions is the neoclassical consumer theory of housing demand (Megbolugbe et al., 1991). Therefore, our theoretical framework for this research, "housing and other goods theory" is from the neoclassical theory of consumer choice. This theory was developed by Jameson \& Nana (2004). From a theoretical base, the trade-off between spending on housing and spreading on other items in the consumption basket follows from the neo-classical 
theory of consumer choice. The outcome of such trade-off is determined as a result of the interaction between an individual's preferences (tastes) and budget constraints. This theory assumed that there are only two items in the consumption basket, housing and all other goods needed for a healthy living by a household (non-housing needs). The main thesis of the theory is that there is always a trade-off between spending on housing and other non-housing item in the consumption basket of a household. The key aspect of this theoretical model that makes it appropriate for our theoretical framework in this research is that it represents an argument that the choice between housing and other goods depends on the preferences, household income and price of housing relative to the price of other non-housing goods. Thus, if any of these three influences alter, then the chosen quantity of housing to be consumed may change. Conversely, if housing consumes too high a proportion of the household income, a household will be forced to consume less of other goods of necessity (non-housing goods). However, since housing cannot be consumed in part, and certain minimum must always be consumed by a household, too often, housing usually take first priority; and it is whatever that is left that is available for other non-housing goods of necessity. Housing affordability measurement is a measure of degree of incursion of housing expenditure into what the household will normally expend on other non-housing necessities. This theory provided the bases for the residual income approach to measure housing affordability and for this research (Figure $1)$.

\section{Literature Review}

The term housing affordability simply implies the ability to afford housing. However, beyond this point, any attempt to precisely define and grapple with the concept becomes slippery. The term housing affordability comes to popular

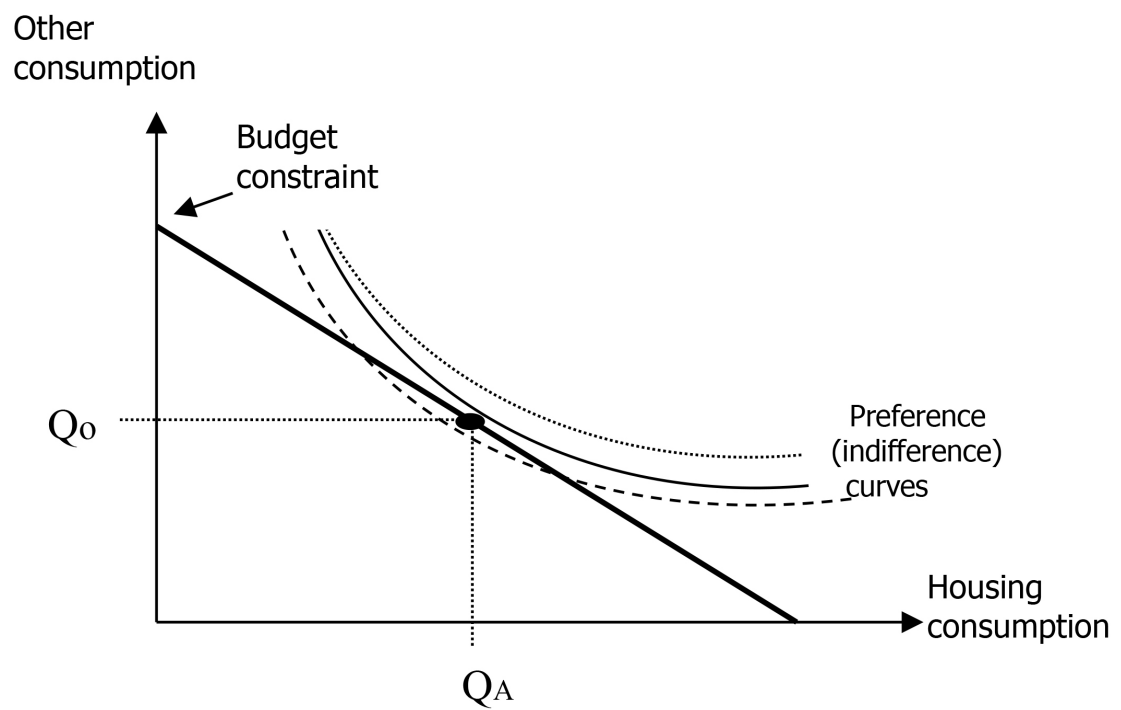

Figure 1. Choosing between housing and other consumption goods. Source: Jameson, B \& Nana, G. (2004), p. 11. 
usage in the last three decades replacing "housing need" at the centre of debate about the provision of adequate housing for all (Whitehead, 1991; Swarts and Miller, 2002). Although "affordability has been in widespread use in US housing policy since 1960s, it was not until late 1980s that it became part of policy discourse in Australia and UK. Its usage can be traced to the promotion by governments of neo-liberal modes of housing. Confirming this view, Heywood (2004) and Linneman \& Megbolugbe (1992) asserted that the shrinking role of the state in many developed countries over the past three decades due to neo-liberal economic policies brought housing affordability to the fore in global housing discourse. The adoption of neo-liberal economic policies in Nigeria led to the adoption of the current national housing policy with emphasis on the market and private sector driven housing provision. This paradigm shift has therefore make clarity and measurement of housing affordability imperative in Nigeria.

Generally, affordability is a measure of ability and capacity of consumer to pay for goods and services to be consumed. Therefore, in a market economy, price will not only allocate quantity, but also, the quality of goods and services that each household will consume based on their level of affordability. According to UNCHS/HABITAT (1991), housing affordability is an assessment that relates a particular housing solution to the amount that can be paid for without unduly stretching the payer's resources. This view of affordability is of wider applicability, as it is applicable to renters, as well as those who want to build or buy their houses without recourse to mortgage facility. According to Arthur et al., 2002), housing affordability is more difficult to define as it involves the capacity of households to consume housing services, specifically, it involves the relationship between household incomes and housing prices and rents. Maclennan and Williams (1990) gave one of the most quoted definition of housing affordability as "a measure with securing some given standard of housing (or different standards) at a price or rent which does not impose, in the eye of some third party, (usually government) an unreasonable burden on household income.

In a more explicitly way, Whitehead (1991) pointed out that definitions of housing affordability usually focus on the relationship between housing expenditure and household income and that they seek to establish a standard in respect of which the amount of income spent on housing is defined unaffordable. This standard can be defined in terms of absolute residual income, once housing costs have been met or as a ratio measure, specifying the acceptable proportion to be spent on housing.

However, in a mortgage-based housing delivery, housing affordability can be conceptualized as ability and capability of household to meet their periodic mortgage obligations without jeopardizing their health or reducing their family nutrients intake (Agbola, 1990; Olatubara \& Agbola, 1992). This is mortgage affordability; the ability to meet all requirements to quality to raise enough fund through mortgage to buy a house. On the other hand, repayment affordability considers the burden imposed on a household of repaying the mortgage and ability to cope without failing to meet other non-housing necessities. Income af- 
fordability is simply a measure of the ratio of house prices to household income. Finally, there is the renter housing affordability which specifically measures the ability of renters to pay rent of a minimum standard housing without jeopardizing the ability to meet other non-housing needs. All these variants of housing affordability further attests to its complexity, contentious nature and implications for different segments of the population.

The contestation in housing affordability debates does not end with its definition. The greater debate is in the approaches to measuring housing affordability. Notwithstanding the controversies in the housing affordability measure methods/approaches, it has gained wider global recognition and acceptance in housing policy outcomes analysis. According to Bramley (2012) affordability measure, over the last 25 years, has become a more commonly used even ubiquitous, term in housing policy discourse. Affordability measure has come as the most concrete measure to relate anticipated policy outcomes to the households, and therefore has become a kind of acid test for the analysis of policy outcomes. However, due to its increasing popularity, acceptability and application, housing affordability measure has equally become extremely controversial, generating intense intellectual discourse and ultimately leading to refinement in operational modalities. This intellectual debate has pitched the proponents of housing affordability measure into two major divides (Adegoke, 2016).

Therefore, most recent research efforts and debates are concerned about how the affordability measure should be operationalized, particularly whether a housing costs-to-income ratio approach or residual income relative to subsistence approach should be adopted (Bramley and Kantley, 2004; Kutty, 2005; Stone, 2006; Gan and Hill, 2009; Chen, et al.; 2010 and Bramley, 2012). According to Stone (2006), mathematically, the relationship between housing costs and income can be computed either as ratio or as a difference. These two approaches are the formal foundation of the prevailing affordability paradigm and its principal challenger respectively.

Housing costs-to-income ratio approach expressed affordability as the ratio of housing costs to the household income (Kutty, 2005). This approach has the longest history and widest recognition (Stone, 2006). It is the most common measure of housing affordability (Chen, 2011). The threshold of the price or housing expenditure-to-income has been set at $25 \%, 30 \%$ and $50 \%$ and households that exceed these ratios are regarded as having housing affordability problem (Kutty, 2005). Housing costs-to-income approach appealed to many researchers and professionals because of its "mathematical simplicity," also, because ratios are pure numbers, they can be compared across time and space and are susceptible to being verified as universal and lawful (Stone, 2006). However, despite the widespread recognition and acceptance of this approach, it has several drawbacks which invariably led to agitation for an alternative approach (Adegoke, 2016). Prominent among the flaws are lack of theoretical foundation for the concept or particular ratio or ratios that are used; it ignores differences in quality and preference (Kutty, 2005; Stone, 2005). It also fails to 
appreciate/capture income constraints and differentials among household and cannot distinguish between households that willingly and those that are forced to spend more than $30 \%$ of their income on housing.

Residual income approach emerged as a result of the perceived flaws and several criticism of the ratio approach. Mathematically, it is a measure of the difference between household housing expenditure and the household income. This approach relied on the fact that for the fast majority of households, housing expenditure is by far the single largest chunk of their income. According to Stone (2006), the approach arises from the recognition that because of housing's distinctive physical attributes in comparison with other necessities its costs makes the largest and least flexible claim on after-tax income for most households. This approach can also be anchored on the "housing and other goods theory" by Jameson \& Nana (2004), where he asserted that: "from a theoretical base, the trade-off between spending on housing and spending on other goods in the consumption basket follows from the neo-classical theory of consumer choice. The outcome of such a trade-off is determined by a result of the interaction between an individual's preferences (tastes) and their budget constraints" (Jameson \& Nana, 2004). In essence therefore, the non-housing expenditures are limited by how much is left after paying for housing consumption. Essentially, residual income approach measures whether the household's income after deducting the costs of standard housing consumption is sufficient to meet minimum acceptable non-housing consumptions. Thereafter, the approach indicators of housing affordability should be the difference between housing costs and the residual income after paying for housing (Luffman, 2006). Stone, a leading advocate and proponent of residual approach further clarified the approach in his publication when he developed the concept of "shelter poverty" which he described as a situation when housing costs are too high that household cannot meet the minimum acceptable non-housing consumption. Kutty (2005) similarly came up with "housing induced poverty," which he described as the situation when a household cannot afford the minimum non-housing goods after paying for housing. The strength of residual income approach includes taken the housing decisions of individual households and socially acceptable level of consumption into consideration; which make it possible to establish under and over consumption. This approach also offers a more precise treatment of how to identify housing needs and problems, which promotes the allocation of housing subsidies in a more efficient and impartial way (Kutty, 2005); Stone and Chen, 2010; Stone et al.; 2011; Bramley, 2011). One major weakness of residual income approach however remains how to define and establish the "minimum standards" of adequacy for non-housing consumption (Gabriel et al.; 2005; Stone, 2006; Yang, 2001; Yang \& Chen, 2014).

By and large, residual income approach has enriched the debate on housing affordability measure by introducing some variables which invariably make it to capture more aspects of housing affordability that ratio approach neglected. Despite that, Stone and one of the strongest advocates of the adoption of residual 
income approach, admitted that residual income is neither well known nor widely understood, let alone accepted. That notwithstanding, the approach is sound and very robust and sooner or later, it will effectively compete with, if not replace the traditional paradigm of housing affordability measure (Stone et al., 2011). Generally however, whichever of the two major approaches that will be employed; the starting point is to properly define housing affordability. According to Bramley and Karley (2004) affordability is of a decent home, within the means of the family. While affordability ratios measure the "housing costs-to-income," residual income approach measures "what percentage of income is left" (residual) relative to subsistence needs after paying for housing.

This review of literature has revealed absence of serious theoretical efforts and application of the two major contemporary measures of housing affordability and a narrow application of measure of repayment affordability in public housing scheme in Nigeria. More importantly, there is a noticeable dearth of empirical investigation of housing affordability of urban dwellers in Nigeria at a national scale and across all income groups. This therefore exposed major research gap in national housing affordability. This research fills this major gap and provides a basis for contributions to the ongoing global debates on housing affordability from the Nigerian perspectives. More importantly, this research is becoming imperative in view of the rising costs and increasing housing deficit; as well as rising homelessness and increasing vacancies currently emerging in Nigeria urban centres.

\section{Research Setting and Methodology}

\subsection{Research Setting}

This study was conducted with the beneficiaries of organized private sector housing estates (OPSHE) developed across the six (6) geo-political zones of $\mathrm{Ni}$ geria. As a result of the new impetus given to private sector participation in 2002, organized private sector real estate developers (REDAN) emerged with members developing housing estates for Nigerians in all parts of the country. Two (2) states with the prevalence of organized private sector housing developers in each of the six (6) geo-political zones were selected. These are the South-West, Lagos and Ogun; in South-South, Edo, and Rivers; South-East, Enugu and Abia; North-Central, Federal Capital Territory, Abuja and Nassarawa; North-West, Kaduna and Katsina and North-East, Bauchi and Gombe.

\subsection{Research Methodology}

A cross-sectional survey design was adopted while multi-stage sampling technique was used to choose residents of the sampled estates for an interview (Creswell, 2013; Patton, 1990). Ten Percent (1950) household heads were randomly selected from the occupied houses $(19,500)$ in the estates. Two (2) sets of structured questionnaire were administered; one set on the organized private sector housing developers (OPSHs) and the other set on the residents of the es- 
tates. Ten percent (1950) households were randomly selected from all the occupied houses $(19,500)$ in the selected estates across the six $(6)$ geo-political zones of the country.

The data collected from the Organized Private Sector Developers (OPSHs) include ownership of company, affiliations, number and types of housing units developed, costs and prices of housing units and location of housing estates among others. The questionnaire for the beneficiaries was used to elicit information on household's social, economic and demographic attributes, particularly household size, income, housing expenditure, choice of housing unit, among others. The information collected was to determine the proportion of household income that goes to housing and to establish the residual thereafter; with the intention to determine the extent of incursion of housing expenditure into what is available for all other non-housing necessities required for a healthy living by a household.

\section{Data Analysis and Results}

This research is anchored on housing and other goods theory and therefore, the data analysis relied on the Residual Income Approach to establish the housing affordability profiles of the beneficiaries. Therefore, the proportion of household income consumed by housing expenditure was calculated and the residual determined. This is because from our anchor theory, we established that by the nature of housing, it cannot be consumed in part, therefore, a certain minimum must always be consumed by a household; and too often, housing usually take first priority, and it is whatever that is left that is always available for other non-housing goods of necessities (Jameson \& Nana 2004). Based on ten percentile scale, the housing affordability profile was analysed; which gave ten groups, viz $1 \%-10 \%, 10.1 \%-20 \%, 20.1 \%-30 \%, 30.1 \%-40 \%, 40.1 \%-50 \%, 50.1 \%$ $60 \%, 60.1 \%-70 \%, 70.1 \%-80 \%, 80.1 \%-90 \%, 90.1 \%-100 \%$.

\subsection{General Housing Affordability of Beneficiaries}

Based on the above, the general housing affordability of beneficiaries was analyzed. The outcome of the analysis revealed that $10.24 \%$ spent $1 \%-10 \% ; 15.36 \%$ spent $10.1 \%-20 \%$ and $16.82 \%$ spent $20.1 \%-30 \%$ of their household income on housing respectively. The households that spent $30.1 \%-40 \% ; 40.1 \%-50 \%$ and $50.1 \%-60 \%$ of their income on housing constitute $16.04 \% ; 20.93 \%$ and $7.68 \%$ respectively. Those household that spent $60.1 \%-70 \%, 70.1 \%-80 \%, 80.1 \%-90 \%$ and $90.1 \%-100 \%$ constitute $6.12 \%, 4.45 \%, 1.22 \%$ and $1.11 \%$ respectively. This is presented graphically in Figure 2.

From the literature Crouch and Wolf (1972), Bunting, Walks and Fillion (2004) and Bramley and Karley (2004) and relying on International Labour Organization (ILO) recommendation of maximum of $30 \%$ of household income for housing expenditure, housing affordability can be categorized into three (3) major groups; these are those spending $1 \%-30 \%, 30.1 \%-50 \%$ and above $50 \%$. The 


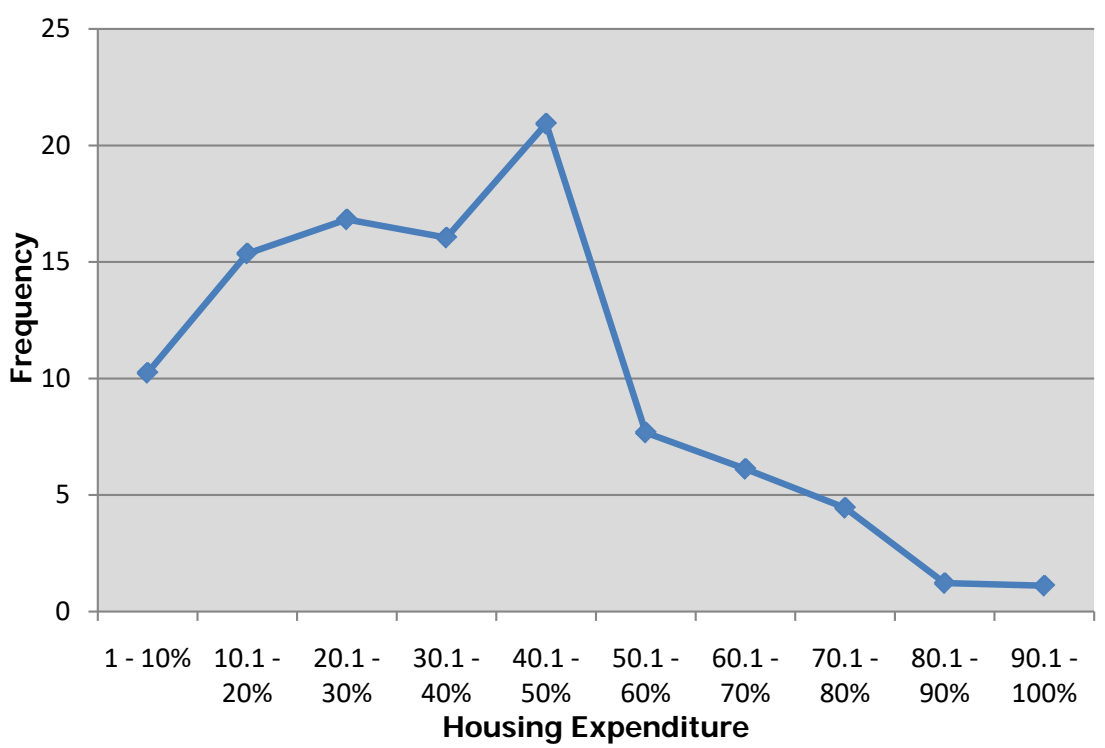

Figure 2. General housing affordability profiles of beneficiaries of organized private sector housing in Nigeria. Source: Computation from Author's Survey Data, 2013.

result of our further analysis based on these groupings revealed that $40.42 \%$ spent between $1 \%-30 \%$ of their household income on housing; while those that spent $30.150 \%$ constitute $44.65 \%$ and those spending above $50 \%$ of their income on housing constitute $12.90 \%$. This categorization of housing affordability of beneficiaries and its implications is as depicted in Figure 3: These categories are Normal Housing Affordability ( $\leq 30 \%)$, Tolerable Housing Affordability (30.1\% $50 \%)$ and Stressed Housing Affordability (>50\%).

1) Zone of Normal Housing Affordability - $1 \%-30 \%$.

2) Zone of Tolerable Housing Affordability - $30.1 \%-50 \%$.

3) Zone of Housing Affordability Stress/Burden - above $50 \%$.

1) Zone of Normal Housing Affordability: This zone comprised those spend between $1 \%-30 \%$ of the household income on housing. This is regarded as normal, because they fall within the maximum housing expenditure canvassed by the International Labour Organization (ILO).

2) Zone of Tolerable Housing Affordability: This is the zone of households that spend between $30.1 \%-50 \%$ of their income on housing. This is still regarded as a tolerable level of income that can be spent on housing without jeopardizing other needs for healthy living, particularly for upper medium and upper income groups.

3) Zone of Housing Affordability Stress/Burden: This is the zone of households that spend between $50.1 \%-100 \%$ of their income on housing. All the households within this zone are under varying degrees of housing affordability stress. The more the housing expenditure is tending towards $10 \%$ of income, the more the household is tending towards homelessness and expulsion from the formal housing market, unless they are assisted by governments, Non-Governmental Organization (NGOs) or individuals, particularly if they belong to low income group. 

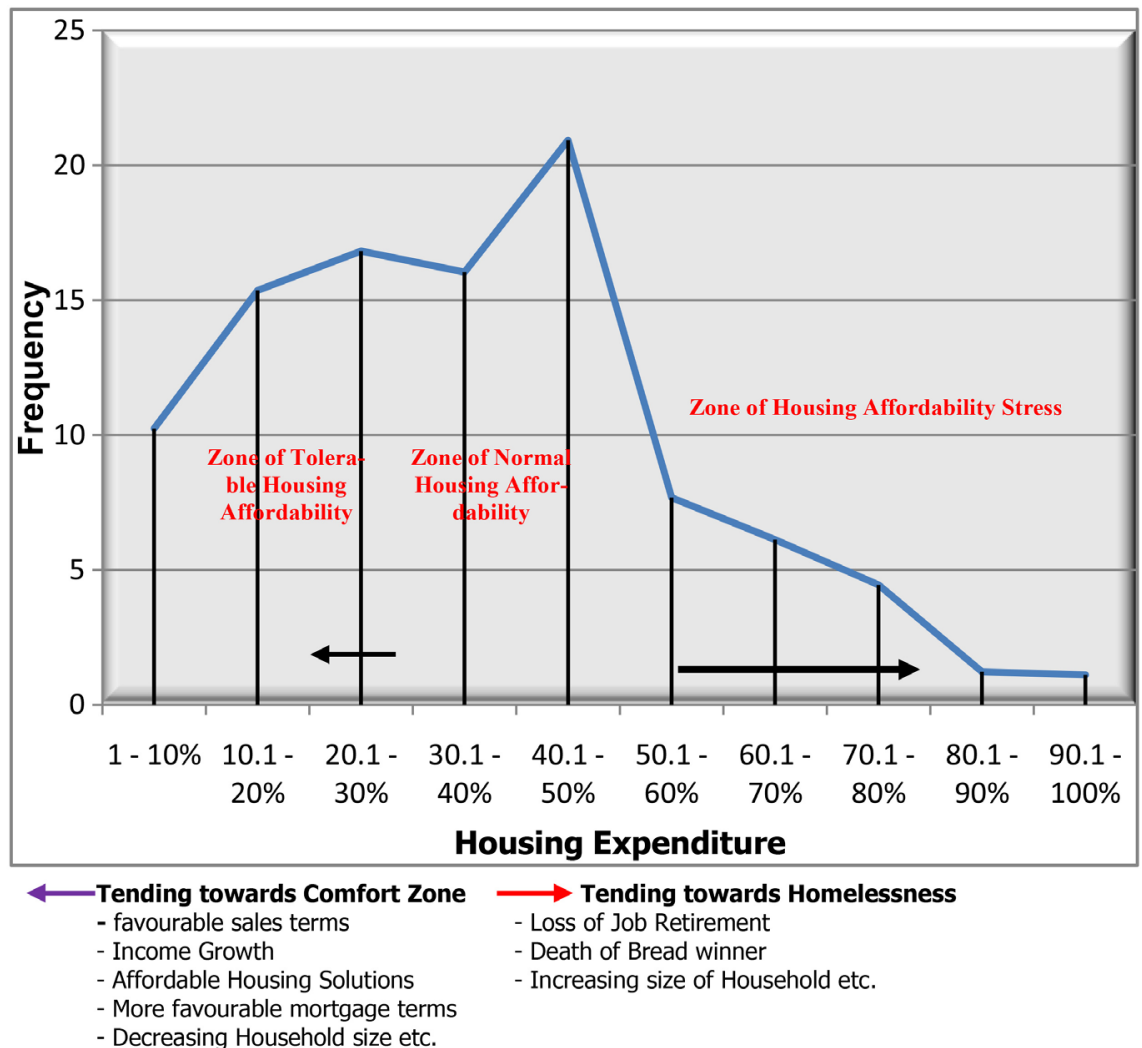

Figure 3. Categorization of housing affordability of beneficiaries and its implications.

\subsection{Housing Affordability of Beneficiaries}

Based on households' income, it has been established in the literature that housing affordability varied with household income. Even, the proportion of household income that can be expended on housing without jeopardizing other essential obligations of living varied with income group of household. Thus, while high income household can afford to spend higher proportion of the income (over and above 30\%) on housing without sacrificing other essentials of healthy living, low and medium income households can spend even less than $30 \%$ and still have serious housing affordability stress. The disaggregation of beneficiaries into different income groups revealed that only about $6 \%$ are in low income category, about $25 \%$ fall within the medium income group while the majority, about $70 \%$ is in the high income bracket.

Our further analysis revealed that only about $7 \%$ of low income earners spent between $1 \%$ and $30 \%$ of their household income on housing; $19.35 \%$ spent between $30.1 \%$ and $50 \%$; while the majority, about $74 \%$ spent between 50.1 and $100 \%$ of their income on housing. This means that about $93 \%$ of low income earners are under varying degrees of housing affordability stress/burden. It was also revealed that among the medium income group, only about $25 \%$ fall within normal housing affordability zone, $35 \%$ fall within tolerable housing affordability or marginal housing affordability zone while about $42 \%$ fall within severe housing affordability stress zone. However, the high income group fares better, 
with 53\% falling within the normal housing affordability zone or the comfort zone; about $38 \%$ within tolerable housing affordability or marginal housing affordability stress zone; while only $9 \%$ are within the severe housing affordability stress/burden zone. In all, about $91 \%$ of high income earners are within the normal and tolerable housing affordability zones. This is illustrated in Figure 4: Housing Affordability of Beneficiaries based on households' income.

\subsection{Housing Affordability of Beneficiaries}

The findings clearly show that the Organized Private Sector Housing is not affordable to most Nigerians. This also explains the growing vacancies in most of the estates developed by the Organized Private Sector Developers. Therefore, there is the urgent need for policy intervention, particularly to help those who are under severe housing affordability stress. The findings also confirm the need to assist the vulnerable and disadvantaged group to enhance their housing affordability.

\section{Findings, Discussion and Policy Implications}

Globally, housing affordability as a concept come to popular usage in about three (3) decades or so, thus replacing "housing need" at the centre of debate about the provision of adequate housing for all (Whitehead, 1991; Swarts and Miller, 2002). Heywood (2004) and Linneman \& Megbolugbe (1992) asserted that the shrinking role of the state in many developed countries over the past three decades due to neo-liberal economic policies brought housing affordability to the fore in global housing discourse. Thus in housing policy formulation and

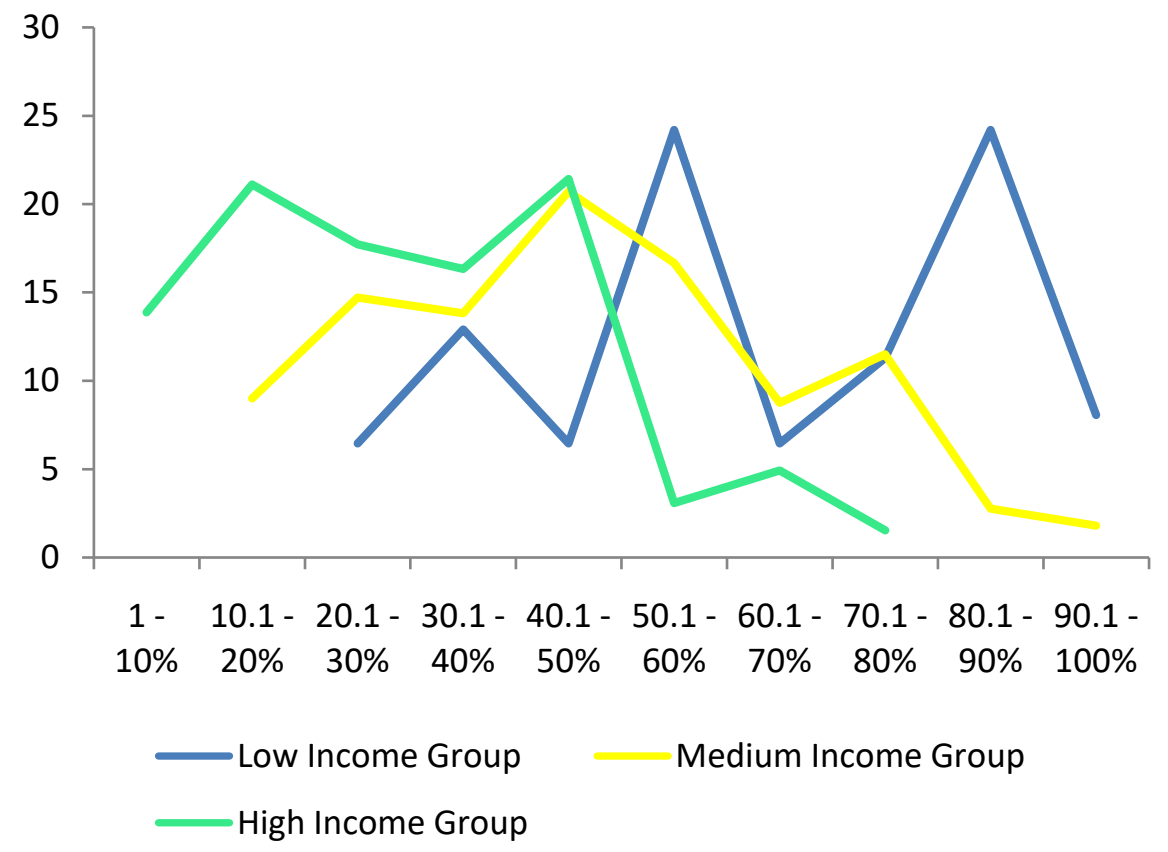

Figure 4. Housing affordability of beneficiaries. Source: Computation from Author's Survey Data 2013. 
outcomes evaluation, housing affordability has today become both a thermostat and a thermometer. Therefore, the major findings of this research will remain highly valuable in policy intervention options in Nigeria. The revelation that only $40.42 \%$ of beneficiaries falls within normal housing affordability zone implied that the aim of the policy that focused on organized private sector housing delivery to ensure "that all Nigerians have access to decent and sanitary accommodation at affordable costs with secured tenure" is far from been achieved. The policy implication of this is that the implementation of this policy has to be monitored, evaluated and subsequently refined to enhance the achievement of the policy objectives. Worst still is the findings from the housing affordability profiles of beneficiaries by income groups. With only about $7 \%$ and $25 \%$ of low and medium income earners falling within normal housing affordability zone, then, it is clear that the organized private sector housing cannot conveniently accommodate these groups. This confirmed the fear expressed by Agbola (2004) that despite the avowed allocation efficiency of a liberalized housing market preached by its proponents, there are fears that a liberalized housing market may inadvertently or deliberately exclude those belonging to the vulnerable and disadvantaged groups.

These findings also validate the arguments of Reis (1992) and Agbola and Alabi (2000) that certain categories of people will always need to be directly provided for, particularly those who will be "inadvertently or deliberately" excluded from the liberalized housing market. Therefore, the major policy implication of the findings from this research is the need to refine the implementation to ensure that more beneficiaries are brought into comfort zone of housing affordability. Also the option of cross-subsidy, where the profit from the luxury housing of the rich is applied to subsidize the price of housing for the low and medium income groups to bring more of them into the comfort zone should be considered. More importantly, the findings from this research will be valuable to government and organized private sector developers to come up with housing options/solutions with liberal purchase terms that will be more favourable to the low and medium income earners. Also, introduction of rent-and-own as well as enhanced mortgage penetration will enhance affordability for the majority of the beneficiaries. Finally, the findings from this research will make a major contribution to global housing affordability debate from the perspective of a developing nation.

\section{Conclusion}

This study has revealed that the organized private sector housing delivery is not affordable to most Nigerians. It also revealed the need to assist some Nigerians, particularly the low and medium income earners. On the whole, the findings from this research showed that while the policy shift from public housing delivery to facilitation of private sector led housing delivery is desirable in line with global paradigm shift, its implementation in the country requires refinement if 
more Nigerians are to own their houses or at least have access to decent affordable housing units. Among the areas to consider for refinement is the need to support the policy with a more efficient mortgage system that will enhance mortgage penetration, particularly among low and medium income earners. Also, the option of "rent-and-own" should be encouraged to accommodate those that may not be able to meet the conventional purchase terms. All these will go a long way to enhance affordability of organized private sector housing in Nigeria and thus help to achieve the policy objective.

\section{Conflicts of Interest}

The authors declare no conflicts of interest regarding the publication of this paper.

\section{References}

Adegoke, S. A. O. (2016). Housing Affordability in Nigeria: A Study of the Organized Private Sector Housing. Unpublished PhD Thesis, Ibadan: Department of Urban and Regional Planning, Faculty of the Social Sciences, University of Ibadan.

Agbola, T. (1990). Affordability and Cost Recovery in Shelter Projects. The Case of Nigeria. Third Planning World Plan Review, 12, 59-74. https://doi.org/10.3828/twpr.12.1.8517204g3773w60t

Agbola, T. (2004). Achieving and Sustaining the Potentials of Housing in the National Poverty Alleviation Programme. In International Housing Summit (pp. 1-45). Abuja: Development Policy Centre.

Agbola, T., \& Alabi (2000). Sustainable Housing Delivery: Lessons from International Experience. In National Workshop on Sustainable Housing Delivery in Nigeria: Challenges for Public/Private Partnership. Abuja: Development Policy Centre.

Bramley, G., \& Karlye, N. K. (2004). Affordability, Needs and the Intermediate Markets: Measurement, Change and Significance. In ENHR Conference (pp. 35-75). Cambridge: University of Cambridge.

Bunting, T., Walks, A., \& Fillion, P. (2004). The Uneven Geography of Housing Affordability Stress in Canada Metropolitan Areas. Housing Studies, 19, 361-393.

https://doi.org/10.1080/0267303042000204287

Centre for Affordable Housing in Africa (2018). Housing Finance in Africa: A Review of Africa's Housing Finance Markets (pp. 35-105). Abidjan: Center for Affordable Housing in Africa.

Chen, J., Yao, Q. J., \& Stephens, M. (2010). Assessing Housing Affordability in Post-Reform China: A Case of Shanghai. Housing Studies, 25, 877-901. https://doi.org/10.1080/02673037.2010.511153

Creswell, J. W. (2013). Qualitative Inquiry and Research Design: Choosing among Five Approaches (3rd ed.). Washington DC: Sage.

Crouch, C., \& Wolf, M. (1972). Inequality in Housing. In P. Townsend, \& N. Bosanquet (Eds.), Labour and Inequality (pp. 145-165). London: The Fabian Society.

Gabriel, M., Jacobs, K., Arthurson, K., Burke, T., \& Yates, J. (2005). Conceptualizing and Measuring the Housing Affordability Problem. National Research Venture 3: Housing Affordability for Lower Income Australians. Reports for May, Melbourne Victoria: Australian Housing and Urban Research Institute.

Heywood, F. (2004). Understanding Needs: A Starting Point for Quality. Housing Stu- 
dies, 19, 709-726. https://doi.org/10.1080/0267303042000249161

Jameson, B., \& Nana, G. (2004). Furthering Our Understanding of Tenure Transition: The Impact of Financial Circumstances on Tenure Choice in New Zealand (pp. 125-156). New Zealand: Business and Economic Research Limited.

Kutty, N. K. (2005). A New Measure of Housing Affordability: Estimates and Analytical Results. Housing Policy Debate, 16, 113-142. https://doi.org/10.1080/10511482.2005.9521536

Linneman, P. D., \& Megbolugbe, I. F. (1992). Housing Affordability: Myth or Reality? Urban Studies, 29, 369-392. https://doi.org/10.1080/00420989220080491

Luffman, J. (2006). Measuring Housing Affordability. Perspectives on Labour and Income, 7, 16-25.

Maclennan, D., \& Williams, R. (1990). Affordable Housing in Britain and America. York: Joseph Rowntree Foundation.

National Bureau of Statistics NBS (2015). National Bureau of Statistics, Nigeria. https://knoema.com/atlas/sources/NBS-NG

Ndubueze, O. J. (2009). Urban Housing Affordability and Housing Policy Dilemmas in Nigeria. Thesis, Birmingham: University of Birmingham for the Degree of Doctor of Philosophy, Center for Urban and Regional Studies, School of Public Policy.

Olatubara, C. O., \& Agbola, S. B. (1992). Cost Recovery in Nigerian Public Housing. Habitat International, 16, 83-94. https://doi.org/10.1016/0197-3975(92)90010-V

Oyo-Ita (2017). Tackling the Housing Affordability Challenge: Nigeria Experience. In 30th International Union of Housing Finance (IUHF) World Congress on "Global Opportunities in Housing Finance" (pp. 1-20).

Patton, M. Q. (1990). Qualitative Evaluation and Research Methods. Thousand Oaks, CA: SAGE Publications.

Reis, P. M. O. (1992). Non-Conventional Housing Finance in Nigeria. Unpublished PhD Thesis, London: Council for National Academic Awards (UK), Architectural Association School of Architecture.

Stone, M. E. (2005). A Housing Affordability Standard for the UK. Housing Studies, 21, 453-476. https://doi.org/10.1080/02673030600708886

Stone, M. E. (2006). What Is Housing Affordability? The Case for the Residential Income Approach. Housing Policy Debate, 17, 151-184.

https://doi.org/10.1080/10511482.2006.9521564

Stone, M., Burke, T., \& Ralston, L. (2011). The Residential Income Approach to Housing Affordability: The Theory and the Practice.

UNCHS/HABITAT (1991). Housing Finance. Manual for Developing Countries. A Methodology for Designing Housing Finance Institutions. Nairobi: United Nations for Human Settlement (Habitat).

Whitehead, C. (1991). From Need to Affordability: An Analysis of UK Housing Objectives. Urban Studies, 28, 871-887.

World Bank (2018). The World Bank Annual Report 2018. Washington DC: World Bank Group.

Yang, Z. (2001). An Application of the Hedonic Model with Uncertain Attribute: The Case of the People's Republic of China. Property Management, 19, 50-63. https://doi.org/10.1108/02637470110366202

Yang, Z., \& Chen, J. (2014). Housing Affordability and Housing Policy in Urban China. Berlin: Springer. https://doi.org/10.1007/978-3-642-54044-8 